\title{
Responses to inclusion of fat of different saturation degrees in concentrates offered to lactating grazing cows ${ }^{1}$
}

\author{
José Pantoja ${ }^{2}$, Paul Randel ${ }^{3}$ and Teodoro Ruiz ${ }^{4}$
}

J. Agric. Univ. P.R. 89(1-2):39-49 (2005)

\begin{abstract}
Forty cows were supplemented with concentrate feed containing added fat with different degrees of saturation, offered individually twice daily at a rate of $0.5 \mathrm{~kg} / \mathrm{kg}$ of milk produced. For two weeks, beginning the second week of lactation, they received a pre-treatment diet to obtain data for use in subsequent analyses of covariance. The cows were assigned to blocks according to parity ( $1^{\text {st }}$ or $\left.\geq 2^{\text {nd }}\right)$, date of calving, previous milk production (multiparous) or milk production during the pre-treatment period (primiparous). For the 6-wk comparison period the cows were randomly assigned to one of the following treatments: concentrate with no added fat (C); or with $5.9 \%$ fat from added tallow (T, low saturation level); a 50:50 mixture of tallow and partially hydrogenated tallow (T-PHT, intermediate saturation level); or all partially hydrogenated tallow (PHT, high saturation level). A forage dry matter intake of $5 \mathrm{~kg} /$ day was assumed for all treatments. The fat-supplemented diets partially replaced ground corn. Estimated net energy content of the experimental diets was 1.54 and $1.63 \mathrm{Mcal} \mathrm{NE}_{\mathrm{L}} / \mathrm{kg}$ for the control and fat supplemented diets, respectively. Daily intake of concentrate feed tended to be higher in the cows supplemented with fat $(P=0.09 ; 12.4,13.1,12.5$ and $13.1 \mathrm{~kg}$ for C, T, T-PHT and PHT, respectively) and responded in a quadratic manner to the level of fat saturation $(P<0.05)$. The treatments did not significantly affect milk production $(25.5,24.9,25.1$ and $25.6 \mathrm{~kg} /$ day). Milk fat percentage was in general low and not affected by treatments $(2.71,2.69,2.79$, and $2.69 \%$ ), whereas milk protein percentage tended $(P=0.09)$ to be lower in the fat-supplemented cows than in the control $(2.87,2.75,2.74$, and $2.69 \%)$. The partial efficiency of $4 \%$ fat-corrected milk production was not affected by fat supplementation $(P>0.05)$, but responded in a quadratic manner $(P<$ 0.05 ) to level of fat saturation, reflecting the lower daily concentrate consumption in the cows supplemented with the T-PHT $(1.61,1.55,1.77,1.56 \mathrm{~kg}$ of milk/ kg of concentrate intake, respectively). No differences were detected in visual body condition score of the cows on different treatments. Body weight change of the cows was not affected by fat supplementation; however, among those supplemented it tended $(P=0.07)$ to vary inversely with level of fat saturation. The inclusion of fat in the concentrate feed of cows under grazing conditions showed evidence of exerting beneficial effects on consumption of concentrates with minor effects on performance.
\end{abstract}

${ }^{1}$ Manuscript submitted to the Editorial Board 21 November 2003.

${ }^{2}$ Extension Dairyman, Department of Animal Industry, P.O. Box 3460, Manatí, PR 00674.

${ }^{3}$ Animal Nutritionist, Department of Animal Industry.

${ }^{4}$ Associate Animal Husbandman, Department of Animal Industry. 
Key words: fat supplementation, fat saturation, lactating cows, grazing conditions, milk yield, concentrate intake

\section{RESUMEN}

Respuesta a la inclusión de grasa con diferentes grados de saturación en el alimento concentrado ofrecido a vacas lactantes

Alimentos concentrados que contenían grasas con diferentes índices de saturación se añadieron a la dieta de cuarenta vacas Holstein; éstos se ofrecieron dos veces al día a razón de $0.5 \mathrm{~kg} / \mathrm{kg}$ de leche producida, para evaluar respuestas productivas. Las vacas recibieron una dieta pre-tratamiento por dos semanas, comenzando en la segunda semana de lactancia. Los datos obtenidos durante dicho periodo de tiempo se utilizaron para subsiguientes análisis de co-varianza. Las vacas se agruparon en bloques de acuerdo al número de lactancias $\left(1^{\mathrm{ra}} 0 \geq 2^{\mathrm{da}}\right)$, fecha de parto, producción previa de leche (multíparas) o producción de leche durante el periodo pre-tratamiento (primíparas). Durante el periodo de comparación de seis semanas las vacas se asignaron al azar a uno de los siguientes tratamientos: concentrado sin grasa añadida (C); con $5.9 \%$ de grasa añadida no saturada de cebo de res $(T$, nivel bajo de saturación); una mezcla de 50:50 de cebo de res y grasa saturada artificialmente (T-PHT, nivel intermedio de saturación); 0 con grasa saturada artificialmente (PHT, nivel alto de saturación). Se asumió un consumo promedio de forraje en pastoreo de $5 \mathrm{~kg} /$ día de materia seca en todos los tratamientos, $y$ en las dietas suplementadas se sustituyó parcialmente el maíz partido por grasa animal. El contenido de energía neta estimado de las dietas experimentales fue de 1.54 y $1.63 \mathrm{Mcal}^{N_{\mathrm{L}}} / \mathrm{kg}$ para las dietas control y con el suplemento de grasa, respectivamente. El consumo de alimento concentrado (12.4, $13.1,12.5$ y $13.1 \mathrm{~kg} /$ día para C, T, T-PHT y PHT, respectivamente) en promedio tendió a ser mayor en las vacas con el suplemento de grasa $(P=0.09)$ y respondió en forma cuadrática al nivel de saturación de grasa $(P<0.05)$. No hubo efectos de tratamientos sobre la producción de leche $(25.5,24.9,25.1$ y 25.6 $\mathrm{kg} / \mathrm{di} a)$. En general, los porcentajes de grasa en la leche fueron bajos y no se afectaron con los tratamientos $(2.71,2.69,2.79$ y $2.69 \%$, respectivamente), mientras que los porcentajes de proteína tendieron a ser menores en las vacas con el suplemento de grasa comparado con aquellas en la dieta control $(2.87,2.75,2.74$ y $2.69 \% ; P=0.09)$. La eficiencia para producción de leche ajustada para $4 \%$ de grasa no se afectó por la adición de grasa a la dieta (P > $0.05 ; 1.61,1.55,1.77,1.56 \mathrm{~kg}$ de leche/kg de alimento concentrado, respectivamente), pero respondió en forma cuadrática $(P<0.05)$ al nivel de saturación de la grasa. No se observaron diferencias asociadas con los tratamientos, en la evaluación de la condición corporal de las vacas. El cambio en peso corporal de las vacas no se afectó con la adición de grasa; sin embargo, entre las vacas con el suplemento de grasa el cambio en peso corporal tendió $(P=$ $0.07)$ a variar inversamente con el nivel de saturación de la grasa. La inclusión de grasas en el alimento concentrado de vacas bajo condiciones de pastoreo aparenta ser beneficiosa para el consumo de alimento concentrado y tiene efectos menores en el comportamiento productivo.

Palabras clave: saturación de grasa, suplementos de grasa, vacas lactantes, alimento concentrado

\section{INTRODUCTION}

The dairy industry is the most important agricultural enterprise of Puerto Rico. Despite its prominent place, it is affected by several problems: high dependence on concentrate feed made locally from imported 
ingredients and low levels of effective fiber intake. The reasons for the inadequate fiber consumption in Puerto Rican dairy cows are various. The use of high stocking rates, more than seven head per hectare, and increasing (ORIL, 2002), produces a shortage of forage during the cool season of the year. Poor management of the existing pastures (RamosSantana and Randel, 1996), characterized by low levels of fertilization, in part due to the small price differential between concentrate feeds and synthetic fertilizers. On the other hand, dependence on grazing as the principal way of harvesting forage limits forage intake and milk production by Holstein cows in the tropical environment, especially as that dependency increases (National Academy of Sciences Press, 1981).

The inclusion of fat in dairy diets offers several opportunities for improving the efficiency of energy utilization. The energy concentration in fat is 2.5 times that of carbohydrates, all of which may allow higher energy consumption and milk yield if energy intake is a limiting factor. The transfer of dietary fatty acids to milk fat is more efficient than mammary synthesis from volatile fatty acids and avoids the caloric load associated with carbohydrate fermentation. The opportunity for substituting fat for rapidly fermentable carbohydrates in the diet may allow an improvement in the proportion of forage fiber in the total dietary carbohydrates, even at the same level of forage intake, theoretically improving rumen fermentation, fiber digestion and consequently normalizing milk fat tests and production.

Extensive research has demonstrated that up to $6 \%$ supplemental fat can be included in the diet of lactating cows (Palmquist, 1988). Approximately $3 \%$ of that fat can be from conventional sources (lower in price) such as tallow or animal vegetable fat, and 2 to $3 \%$ from rumen inert fats. One of the factors limiting the use of unsaturated fats is their inhibitory effect on ruminal fiber digestion (Jenkins and Jenny, 1989). Most of the work evaluating fat supplementation has employed alfalfa and corn silage as the forage fed as total mixed rations (Drackley et al., 2003; Jerred et al., 1990; Pantoja et al., 1994). Grazing cows supplemented with 0.25 and $0.50 \mathrm{~kg} /$ day of prilled fat had higher peaks of fat corrected milk at the higher level of supplementation (Dugmore and Walsh, 1990). Despite the potential advantages of the use of dietary fats under heat stress conditions, no research data have been published evaluating fat supplementation under local conditions. Few data are available on fat supplementation under grazing, and even fewer where tropical grasses are the only forage source and concentrate supplementation is intensive.

The present study was undertaken to evaluate lactational performance of cows under grazing conditions, supplemented with concentrates that contain a conventional or a saturated fat source or a combination of both. 


\section{MATERIALS AND METHODS}

The trial was conducted at the Gurabo Agricultural Experiment Station, located in the eastern part of Puerto Rico (long. $66^{\circ} \mathrm{W} 12^{\circ} \mathrm{N}$, approximately $15 \mathrm{~km}$ from the coast and $115 \mathrm{~m}$ above sea level). Data were collected from December 1997 through August 1998. Forty cows (multiparous and primiparous, average initial body weight of $510 \mathrm{~kg}$ ) were fed a pre-treatment diet during weeks 2 and 3 of lactation. Data collected during this period were used for covariate adjustment of lactation performance during the subsequent treatment period. Cows were blocked by parity ( $1^{\text {st }}$ or $\geq 2^{\text {nd }}$ ), calving date and previous milk production (multiparous), or by milk production during the pre treatment period (primiparous), and randomly assigned to four diets within blocks to evaluate the effects of fat supplementation and degree of fat saturation on performance. Experimental concentrates were fed from week 4 to week 10 of lactation. Concentrates were control (C) with no supplemental fat; concentrate with 5.9\% fat from tallow ( $\mathrm{T}$, low level of saturation; Ganaderos Alvarado, Inc., Arecibo, $\mathrm{PR}^{5}$ ); 50:50 tallow and partially hydrogenated tallow (T-PHT, intermediate level of saturation; Milk Specialties Co., Dundee, IL); and partially hydrogenated tallow (PHT, high level of saturation). Diets were formulated for $30 \mathrm{~kg}$ of milk per day, assuming a minimum of $5 \mathrm{~kg} /$ day of forage intake under grazing and balanced to meet or exceed NRC (1989) recommendations for protein, NDF, minerals and vitamins.

During the pretreatment and treatment periods concentrate was allocated at a rate of $0.5 \mathrm{~kg} / \mathrm{kg}$ milk produced per 14-day period and fed daily at 9:00 and 13:00 h. Samples of concentrates were taken with each new batch and analyzed for dry matter, nitrogen (AOAC, 1984), NDF (Van Soest et al., 1991) and minerals by emission spectroscopy at the Dairy One Forage Laboratory in Ithaca, NY. The energy concentration of the concentrate was estimated by using the equation of Weiss et al. (1992).

All cows grazed on an area of 20.93 ha divided into 10 paddocks, varying in size from 0.99 to 2.83 ha rotationally grazed according to forage availability, all of which resulted in an average grazing cycle of 23 days. The stocking rate for all treatments was 5.0 cows per hectare. The sward consisted of mixed grasses, mainly star grass (Cynodon nlemfuensis) and guinea grass (Panicum maximum). Fertilization was at a rate of 2,240 kg of fertilizer per hectare (15-5-10 analysis) divided into four applications.

\footnotetext{
${ }^{5}$ Trade names in this publication are used only to provide specific information. Mention of a trade name does not constitute a warranty of equipment or materials by the Agricultural Experiment Station of the University of Puerto Rico, nor is this mention a statement of preference over other equipment or materials.
} 
Cows were milked at 06:00 and 14:00 h. Milk production was measured and recorded daily by using a meter approved by NCDHIP. Individual milk samples were taken weekly at both milkings for two consecutive days for subsequent analysis of milk fat and protein concentration (PRDHI, Dorado, PR). Protein and fat concentration were weighed according to respective milk production at each milking over both days to obtain mean weekly concentrations. Cows were weighed every two weeks. The body condition of the cows was estimated as described by Wildman et al. (1982) at the beginning and at the end of the pre-treatment period (start of weeks 2 and 4 of lactation) and every 28 days thereafter.

Production data were analyzed as a complete block design. Treatments by milk yield interactions were evaluated by using the repeated measure procedure of SAS (1988), but none were detected $(\mathrm{P}>0.10)$. Data were reduced to mean by cow and subjected to ANOVA by using the general lineal model procedure of SAS (1988). All data except body weight change were adjusted for the respective pre-treatment data by using covariate adjustment (SAS, 1988). Treatment comparisons were made by the use of single degree of freedom comparison, using the contrast statement of SAS (1988). Contrasts were control versus fat and linear and quadratic effects of fat saturation. Significance is referred to as $\mathrm{P}<0.05$ and tendencies as $0.05<\mathrm{P}<0.10$, unless otherwise indicated.

\section{RESULTS AND DISCUSSION}

Table 1 presents the ingredient composition of experimental concentrates. Chemical composition of these mixtures is not available because of problems with laboratory analysis. Diets were formulated for third lactation cows, assuming a daily milk production of $30 \mathrm{~kg}$, to

TABLE 1.-Ingredient composition of experimental concentrates.

\begin{tabular}{lccc}
\hline Ingredient & Pre-treatment & Control & Fat-supplemented \\
\hline & $\ldots \ldots \ldots$ & $\ldots \ldots$ & $\ldots$ \\
Ground corn & 37.20 & 37.20 & 27.40 \\
Soybean meal & 30.70 & 22.30 & 22.60 \\
Wheat middlings & 20.90 & 30.40 & 32.60 \\
Fat source & - & - & 5.90 \\
Cane molasses & 6.50 & 5.70 & 5.80 \\
Fish meal & 2.30 & 1.70 & 1.70 \\
Trace mineralized salt & 0.51 & 0.44 & 0.45 \\
Vitamin A, D and E premix & 0.14 & 0.14 & 0.14 \\
Ground limestone & 1.67 & 1.71 & 3.09 \\
\hline
\end{tabular}


meet or exceed NRC (1989) recommendations. Ground corn was substituted for fat in the supplemented diets. Daily concentrate intake tended to be higher in the cows supplemented with fat $(\mathrm{P}<0.09)$ and responded in a quadratic manner to the level of fat saturation (Table 2). Other studies have reported no effect on total dry matter intake due to fat inclusion when fed as a total mix ration (Pantoja et al., 1994). Chicco et al. (1973) reported similar concentrate intake in cows which received a supplement that contained $3.5,7.0$ or $10.0 \%$ added fat from tallow under grazing conditions. The tendency for higher intake of concentrate in the cows supplemented with fat in the present study may be due to the lower non structural carbohydrate contents of concentrates with fat, which should have produced less ruminal acidity and thus less inhibition of appetite. The reasons for the quadratic response in concentrate consumption to the level of fat saturation need further evaluation. Generally, unsaturated fat tends to be more inhibitory to ruminal fiber digestion than saturated fats. However, dry matter intake from total mixed rations has shown a linear reduction as the level of fat saturation increased (Pantoja et al., 1996). In the present study, concentrate intake expressed as percentage of body weight was not affected by any of the dietary treatments. Total dry matter intake from total mixed rations expressed as percentage of body weight was lower in cows supplemented with fat than in those of the control without fat (Pantoja et al., 1996). It is possible that the effects of fat supplementation on intake under grazing conditions, where the concentrate feeds are offered apart from the forage, may be different from their effects on total mixed rations.

Dietary treatments did not significantly affect milk production or $4 \%$ fat-corrected milk production (Table 2 ). Fat supplementation of a total mixed ration increased milk production in some studies (De Peters et al., 1987; Eastridge, 1991; Pantoja et al., 1996) but not in others (Drackley et al., 2003; Hoffman et al., 1991; Schauff and Clark, 1989). Chicco et al. (1973) reported production levels of $4 \%$ fat-corrected milk in the order of $11.8,11.6$ and $13.2 \mathrm{~kg} /$ day for cows grazing and supplemented with $3.5,7.0$ and $10.5 \%$ added fat in the concentrate feed. Early lactation multiparous cows under grazing conditions had higher peaks of $4 \%$ fat-corrected milk, when supplemented with concentrate feed which contained 0.25 or $0.50 \mathrm{~kg}$ of prilled fat, than the control cows, but no responses were detected in primiparous cows (Dugmore and Walsh, 1990). The inclusion of $1 \mathrm{~kg}$ of supplemental fat daily in the diet of cows grazing a mix of legumes and grasses increased milk production but not fat-corrected milk (Schroeder et al., 2002).

Partial milk production efficiency ( $\mathrm{kg}$ milk $/ \mathrm{kg}$ of concentrate consumed) was similar among cows in the control and those on fat- 
TABLE 2.-Least square means for concentrate intake and production performance for cows fed no supplemental fat (C); added fat in the form of tallow (T); a 50:50 mix of tallow and partially hydrogenated tallow (T-PHT); or partially hydrogenated tallow (PHT).

\begin{tabular}{|c|c|c|c|c|c|c|c|c|}
\hline \multirow[b]{3}{*}{ Item } & \multirow{2}{*}{\multicolumn{5}{|c|}{ Diet }} & \multicolumn{3}{|c|}{ Probability of Contrasts $^{1}$} \\
\hline & & & & & & \multirow[b]{2}{*}{ Fat } & \multicolumn{2}{|c|}{ Saturation } \\
\hline & $\mathrm{C}$ & $\mathrm{T}$ & T-PHT & PHT & $\mathrm{SE}^{2}$ & & Linear & Quadratic \\
\hline Concentrate intake, kg/d & 12.40 & 13.10 & 12.50 & 13.10 & 0.20 & 0.09 & 0.15 & 0.01 \\
\hline Concentrate intake, \% of BW & 2.51 & 2.47 & 2.54 & 2.57 & 0.05 & 0.86 & 0.23 & 0.82 \\
\hline Milk, $\mathrm{kg} / \mathrm{d}$ & 25.50 & 24.90 & 25.10 & 25.60 & 0.90 & 0.77 & 0.74 & 0.85 \\
\hline Milk fat, \% & 2.71 & 2.69 & 2.79 & 2.69 & 0.10 & 0.86 & 0.51 & 0.26 \\
\hline Milk fat yield, $\mathrm{kg} / \mathrm{d}$ & 0.683 & 0.699 & 0.747 & 0.676 & 0.036 & 0.52 & 0.99 & 0.28 \\
\hline Milk protein, $\%$ & 2.87 & 2.75 & 2.74 & 2.69 & 0.07 & 0.09 & 0.97 & 0.55 \\
\hline Milk protein yield, kg/d & 0.694 & 0.722 & 0.745 & 0.662 & 0.051 & 0.80 & 0.58 & 0.56 \\
\hline $4 \%$ fat-corrected milk, $\mathrm{kg} / \mathrm{d}$ & 20.00 & 20.10 & 21.10 & 21.10 & 1.00 & 0.57 & 0.41 & 0.71 \\
\hline Partial milk production efficiency, $\mathrm{kg} / \mathrm{kg}^{3}$ & 2.02 & 1.89 & 2.01 & 1.95 & 0.06 & 0.38 & 0.23 & 0.22 \\
\hline $\begin{array}{l}\text { Partial } 4 \% \text { fat-corrected milk production effi- } \\
\text { ciency, } \mathrm{kg} / \mathrm{kg}^{3}\end{array}$ & 1.61 & 1.55 & 1.77 & 1.56 & 0.07 & 0.82 & 0.17 & 0.02 \\
\hline
\end{tabular}

1Probability of contrasts: fat = control vs. others; saturation = linear and quadratic effects of fat saturation level.

${ }^{2}$ Standard error of means.

${ }^{3}$ Efficiencies relative to concentrate intake. 
supplemented concentrate with different degrees of saturation (Table 2 ). Efficiency of milk production by grazing cows supplemented with fat in a temperate environment was not affected by the inclusion of supplemental fat (Schroeder et al., 2002). The level of supplement in that study was between 5.2 and $6.0 \mathrm{~kg}$ of concentrate daily. Four percent fatcorrected partial milk production efficiency responded quadratically to the level of fat saturation. The higher partial efficiency of $4 \%$ fat-corrected milk in the cows that received the concentrate with the intermediate level of fat saturation was a reflection of the response in concentrate intake, because milk production and milk fat percentage were similar (Table 2).

Milk fat percentages (Table 2) were in general low, reflecting the high dependency of the cows on concentrate supplementation. McDowell et al. (1975) reported a downward trend in milk fat percentage with increasing levels of supplemental feeding in cows grazing tropical grasses. However, even their highest level of supplementation gave milk fat percentages over $3 \%$. The inclusion of fat in the concentrate did not significantly affect milk fat percentage, all of which agrees with other reports from experiments with cows fed a total mixed ration (Erickson, 1992; Hoffman et al., 1991; Sutton, 1989). Garsworthy (1990) has reported higher milk fat percentages in cows supplemented with fat at grazing. Milk fat yield was not affected by the inclusion of fat or by the level of fat saturation in the present study. Schroeder et al. (2002) reported higher milk fat yields in cows supplemented with fat in the concentrate than in those fed concentrates without added fat. The high level of supplementation in our study may have precluded any effect of fat supplementation on milk fat percentage or yield.

Milk protein percentage tended to be lower $(P=0.09)$ in the fat-supplemented cows than in those on the control diet, all of which agrees with most reports (Cant et al., 1993; De Peters et al., 1987; Pantoja et al., 1994) but not with all (Schroeder et al., 2002; Table 2). Depressions in milk protein percentage often observed in fat-supplemented cows have been attributed to increased efficiency of energy utilization and reduced blood flow to the mammary gland (Cant et al., 1993). This theory assumes that blood flow is regulated by energy metabolites but not by amino acid requirements in the mammary gland. Milk protein yields were similar among all experimental treatments. Under grazing conditions, Schroeder et al. (2002) reported similar protein yields in cows supplemented with fat in comparison with those fed a concentrate without fat.

Body weight was not a variable used for treatment assignment, but initial body weights of the cows in the control and fat-supplemented treatments were similar (Table 3 ). However, the cows assigned to the 
TABLE 3.-Least square means for body weight (BW) and body condition score (BCS) measures for cows fed no supplemental fat (C); added fat in the form of tallow (T); a 50:50 mix of tallow and partially hydrogenated tallow (T-PHT); or partially hydrogenated tallow (PHT).

\begin{tabular}{|c|c|c|c|c|c|c|c|c|}
\hline \multirow[b]{3}{*}{ Item } & \multirow{2}{*}{\multicolumn{5}{|c|}{ Diet }} & \multicolumn{3}{|c|}{ Probabilities of Contrasts ${ }^{1}$} \\
\hline & & & & & & \multirow[b]{2}{*}{ Fat } & \multicolumn{2}{|c|}{ Saturation } \\
\hline & $\mathrm{C}$ & $\mathrm{T}$ & T-PHT & PHT & $\mathrm{SE}^{2}$ & & Linear & Quadratic \\
\hline Initial BW, kg & 507.60 & 506.20 & 517.50 & 505.40 & 3.50 & 0.58 & 0.24 & 0.02 \\
\hline Final BW, kg & 521.20 & 526.20 & 511.20 & 497.30 & 9.20 & 0.36 & 0.06 & 0.97 \\
\hline $\mathrm{BW}, \mathrm{kg}^{3}$ & 505.80 & 512.60 & 497.60 & 488.10 & 7.80 & 0.47 & 0.05 & 0.80 \\
\hline BW change, $\mathrm{kg}^{3}$ & 3.29 & 5.22 & 2.02 & -2.27 & 1.00 & 0.53 & 0.07 & 0.85 \\
\hline Initial BCS & 2.61 & 2.69 & 2.70 & 2.66 & 0.04 & 0.29 & 0.80 & 0.73 \\
\hline Final BCS & 2.59 & 2.64 & 2.64 & 2.55 & 0.04 & 0.73 & 0.38 & 0.45 \\
\hline $\mathrm{BCS}^{3}$ & 2.65 & 2.65 & 2.62 & 2.59 & 0.04 & 0.44 & 0.32 & 0.98 \\
\hline
\end{tabular}

Probability of contrasts: fat $=$ control vs. others; saturation = linear and quadratic effects of fat saturation level.

2Standard error of means.

${ }^{8} \mathrm{BW}$ and $\mathrm{BW}$ change and BCS are arithmetic means of observations over the treatment period. 
intermediate level of fat saturation were $11.4 \mathrm{~kg}$ heavier than those in the other treatments. Average body weight responded linearly $(\mathrm{P}=$ 0.05 ; Table 3 ) and final body weight tended to respond in a linear manner to the level of saturation of fat $(\mathrm{P}=0.09$; Table 3$)$. Body weight change tended to decrease in a linear manner with increasing level of fat saturation, so that the cows receiving the most saturated fat lost more body weight. Data are lacking on body weight of cows in continuous lactation studies, especially under grazing. In agreement with the findings of Jerred et al. (1990), body condition scores (BCS) of the cows were not affected by fat supplementation or level of fat saturation (Table 3). In cows fed a total mixed ration, Pantoja et al. (1996) reported a linear tendency for increase in BCS as the level of saturation of fat increased. The inclusion of $6.0 \%$ fat, differing in level of saturation in the concentrate feed of grazing cows in early lactation, showed evidence of enhancing concentrate intake with minor effects on performance.

\section{LITERATURE CITED}

Association of Official Analytical Chemists, 1984. Official methods of analysis. $14^{\text {th }}$ ed. AOAC, Washington, DC.

Cant, J. P., E. J. De Peters and R. L. Baldwin, 1993. Mammary uptake of energy metabolites in dairy cows fed fats and its relationship to protein depression. J. Dairy Sci. 76:2254.

Chicco, C. F., E. D. Schultz and V. Bodisco, 1973. Grasa animal para vacas lecheras bajo condiciones tropicales. Agronomía Tropical 23:577.

De Peters, E J., J. Taylor, C. M. Finley and T. R. Famula, 1987. Dietary fat and nitrogen composition of milk from lactating cows. J. Dairy Sci. 70:1192.

Drackley, J. K., T. M. Cicela and D. W. LaCount, 2003. Resposes of primiparous and multiparous Holstein cows to additional energy from fat or concentrate during summer. J. Dairy Sci. 86:1306.

Dugmore, T. J. and K.P. Walsh, 1990. Milk production responses to feeding fatty acids. South African J. Anim. Sci. 20:35.

Eastridge, M. L. and J. L. Firkins, 1991. Feeding hydrogenated fatty acids and tryglicerides to lactating dairy cows. J. Dairy Sci. 74:2610.

Erickson, P. S., M. R. Murphy and J. H. Clark, 1992. Supplementation of dairy cow diets with calcium salts of long chain fatty acids and nicotinic acid in early lactation. J. Dairy Sci. 75:1078.

Garsworthy, P. C., 1990. Feeding calcium salts of fatty acids in high starch of high fibre compound supplements to lactating cows at grass. Anim. Prod. 51:441.

Hoffman, P. C., R. R. Gummer, R. D. Shaver, G. A. Broderick and T. R. Drendel, 1991. Feeding supplemental fat and undegraded intake protein to early lactation cows. J. Dairy Sci. 74:3468.

Jenkins, T. C. and B. F. Jenny, 1989. The effect of hydrogenated fat on feed intake, nutrient digestion and lactation performance of dairy cows. J. Dairy Sci. 72:2236.

Jerred, M. J., D. J. Carroll, D. K. Combs and R. R. Grummer, 1990. Effects of fat supplementation and immature alfalfa to concentrate ratio on lactation performance of dairy cattle. J. Dairy Sci. 73:2842.

McDowell, R. E., H. Cestero, J. D. Rivera-Anaya, F. Román-García, J. Arroyo-Aguilú, C. M. Berrocal, M. Soldevila, J. C. López-Alberti and S. W. Metz, 1975. Tropical 
grass pastures with and without supplement for lactating cows in Puerto Rico. Univ. P.R. Agric. Exp. Sta. Bull. 238.

National Academy of Sciences, 1981. Effects of environment on nutrient requirements of domestic animals. National Academy of Sciences, Washington, DC.

National Research Council, 1989. Nutrient requirements of dairy cattle. Sixth revised edition. National Academy Press, Washington, DC.

Oficina para la Reglamentación de la Industria Lechera (ORIL), 2002. Informe Anual. Departamento de Agricultura de Puerto Rico. Junio de 2002.

Palmquist, D. L., 1988. The feeding value of fats. R.R. Orston (ed.). In: Feed Science. Elsevier Sci. Publ. A.V., Amsterdam, Nethterlands. p. 293.

Pantoja, J., J. L. Firkins and M. L. Eastridge, 1996. Fatty acid digestibility and lactation performance by dairy cows fed fats varying in degree of saturation. J. Dairy Sci. 79:429.

Pantoja, J., J. L. Firkins, M. L. Eastridge and B. L. Hull, 1994. Effects of fat saturation and source of fiber on site of nutrient digestion and milk production by lactating dairy cows. J. Dairy Sci. 77:2341.

Ramos-Santana, R. and P. F. Randel, 1996. Evaluación de varios aspectos de manejo de forrajes en las vaquerías de Puerto Rico. Univ. PR Agric. Exp. Sta. Bull. 295.

SAS /STAT User Guide, Release 6.03 Edition, 1988. SAS Inst., Inc. Cary, NC.

Schauff, D. L. and J. H. Clark, 1989. Effect of prilled fatty acids and calcium soaps of fatty acids on rumen fermentation, nutrient digestibility, milk production and composition. J. Dairy Sci. 72:917.

Schroeder, G. A., G. A. Gaagliostro, D. Becu-Villalobos and I. Lacau-Mengido, 2002. Supplementation with partially hydrogenated oil in grazing dairy cows in early lactation. J. Dairy Sci. 85:580.

Sutton, J. D., 1989. Altering milk composition by feeding. J. Dairy Sci. 72:2801.

Van Soest, P. J., J. B. Robertson and B. A. Lewis, 1991. Methods for dietary, neutral detergent fiber and non starch polysaccharides in relation to animal nutrition. J. Dairy Sci. 74:3583.

Weiss, W. P., H. R. Conrad and N. R. St. Pierre, 1992. A theoretically based model for predicting total digestible nutrient values of forage and concentrate. Anim. Feed Sci. Technol. 39:95.

Wildman, E. E., G. M. Jones, P. E. Wagner and R. L. Boman, 1982. A dairy cow body condition scoring system and its relationship to selected production characteristics. J. Dairy Sci. 65:495. 


\section{BLANK PAGE USED IN PAGE COUNT}

